\title{
Morphology and anatomy of Rhipsalis cereuscula, Rhipsalis floccosa subsp. hohenauensis and Lepismium cruciforme (Cactaceae) seedlings
}

\author{
Morfología y anatomía de las plántulas de Rhipsalis cereuscula, Rhipsalis floccosa subsp. hohe- \\ nauensis y Lepismium cruciforme (Cactaceae)
}

\author{
Alan C. Secorun and Luiz Antonio de Souza* \\ Departamento de Biologia, Universidade Estadual de Maringá, Avenida Colombo, 5790, (87020-900) Maringá, Paraná, Brasil. \\ "Correspondent: lasouza@uem.br
}

\begin{abstract}
Rhipsalis cereuscula Haw., Rhipsalis floccosa subsp. hohenauensis (F. Ritter) Barthlott et N. P. Taylor and Lepismium cruciforme (Vellozo) Miquel are obligatory epiphytes that occur frequently on tree trunks of remnant forests in Maringa, Paraná state, Brazil. Morphological and anatomical analyses regarding the seedlings were carried out. The seedlings were prepared according to techniques of resin inclusions and histochemical tests. Seedlings were phanerocotyledonar and originated from seeds with operculum. The root was diarch and the hypocotyl presented transition root-stem structure. The cotyledons were sessile, reduced, with homogeneous mesophyll. The epicotyl (phylloclade) presented a lot of parenchyma and reduced vascular cylinder. The 3 studied species showed anatomical characteristics similar to those described for species of Lepismium and Rhipsalis as well as other cacti.
\end{abstract}

Key words: epiphyte, root, hypocotyl, cotyledons, epicotyl, areola.

Resumen. Rhipsalis cereuscula Haw., Rhipsalis floccosa subsp. hohenauensis (F. Ritter) Barthlott et N. P. Taylor y Lepismium cruciforme (Vellozo) Miquel son epífitos obligatorios que frecuentemente habitan en los troncos del árbol de matorrales secundarios de Maringá, Paraná, Brasil. Se analizaron la morfología y anatomía de las plántulas de estas especies. Las plántulas fueron procesadas según las técnicas de inclusión en resina y pruebas histoquímicas. Las plántulas se clasificaron como fanerocotiledonares y se originaron de semillas con opérculo. La raíz era diarca y el hipocótilo presentó estructura de transición raíz-tallo. Los cotiledones fueron sésiles, reducidos, con el mesófilo homogéneo. El epicótilo (filocladio) presentó mucho parénquima y el cilindro vascular reducido. Las 3 especies presentaron características anatómicas similares a las descritas para especies de Lepismium y Rhipsalis, así como otras cactáceas.

Palabras clave: epífito, raíz, hipocótilo, cotiledones, epicótilo, areola.

\section{Introduction}

Epiphytes are plants growing perched on other plants, which differ from parasites in not deriving water or food from the supporting plant and from lianas in not having soil connections. Of all ecological classes of plants these are the most directly dependent on precipitation for their water supply. Their nutrient supply is derived in part from rainwater, which always contains some dissolved substances, in part from accumulated wind-borne particles, and in part from the decaying bark surface of supporting plants. The rich epiphytic flora of a tropical rain forest shows a remarkable gradation from sciophytic hygrophites, confined to the lower trunks of the trees to xerophytes

Recibido: 27 agosto 2009; aceptado: 25 junio 2010 (including cacti) (Daubenmire, 1974). The cacti epiphytes of tropical forests may be attractive for diaspore dispersers, and consequently contribute to the maintenance of the biodiversity (Simão et al., 2007).

The Cactaceae comprises more than 100 genera and 1500 species with distribution almost exclusively to America with centers of diversity in the drier regions of SW USA and Mexico, and southern S America, but Rhipsalis Gaertn. found in Africa and Asia, and several species of Opuntia Mill. have been introduced in Africa, Australia, and India (Barthlott and Hunt, 1993; Judd et al., 2002). Brazil presents 40 genera and 200 species (Souza and Lorenzi, 2005). The northwestern region of Paraná state, Brazil, constitutes a vast area which nowadays presents less than $1 \%$ of the native forest cover. The forest remnants of this region show abundance of epiphytic species of Cactaceae such as Rhipsalis and Lepismium Pfaiff. 
The germination period of the seed, the survivorship and the establishment of the plant in the initial stages of development are critical in the preservation of a species. The first vegetative phase of a plant after the seed germination of the so-called seedling has enormous value in the study of population dynamics, in forestry, in storage of seeds, in arboretum works, and in forest conservation and regeneration (Souza, 2003). Today, it is accepted that studies of plant taxonomy should not be exclusively based on the adult specimen morphology, but should also include the juvenile phases (Millanez et al., 2008).

There is an extensive literature dealing with the morphology and anatomy of Cactaceae seedling, but little attention has been given to the study of Brazilian plants. Ganong (1898) analyzed the comparative morphology of the embryos and seedlings of Cactaceae; Fraine (1910) investigated the seedling structure of 47 species of Cactaceae; Freeman (1969) described the morphology and anatomy of Opuntia basilaris Engelm. et Bigel. Seedlings, Hamilton (1970) studied the seedling structure of Opuntia brandtiana (Coult.) K. Bradegee, Salles (1987) analyzed the seedling morphology of Cephalocereus fluminensis (Miq.) Britton et Rose, Bona et al. (1997) studied the Hatiora gaertneri (Regel) Barthlot seedling, Loza-Cornejo et al. (2003) investigated the morphology, anatomy and photosynthesis metabolism of Stenocereus queretaroensis (Weber) Buxb. seedlings, and Almeida (2009) analyzed the seedling structure of Epiphyllum phyllanthus (L.) Haw.

The present work deals with the morphology and anatomy of the seedlings of Rhipsalis cereuscula Haw., Rhipsalis floccosa subsp. hohenauensis (F. Ritter) Barthlott et N. P. Taylor and Lepismium cruciforme (Vellozo) Miquel. They are obligatory epiphytes that occur frequently on tree trunks of forest remnants of Paraná state, Brazil.

\section{Material and methods}

Reproductive shoots were collected from 3 Cactaceae epiphytes which occur in Parque do Ingá forest remnant (Maringá, Paraná, Brazil). Voucher materials are deposited at UEM Herbarium, collection numbers: Rhipsalis cereuscula Haw. A. L. Secorun 15535, 15536 HUEM; Rhipsalis floccosa subsp. hohenauensis (F. Ritter) Barthlott et N. P. Taylor. A. L. Secorun 15537 HUEM, and Lepismium cruciforme (Vellozo) Miquel. A. L. Secorun 15538, 15539, 15540, 15541, 15542 HUEM.

Seeds were collected, washed in distilled water, and air-dried. One hundred seeds of each species were placed in plastic cages (gerboxes $-11 \times 11 \times 5 \mathrm{~cm}$ ) for germination and seedling growth. For the morphological and anatomical study, 30 seedlings of each species were selected. Seedlings were collected a day after radicle emergence from the seed coat. Seedling age was calculated from the day of the radicle emergence; therefore, the seedling age varied from one day to 200 days.

The materials (proximal root region, collet, hypocotyl, cotyledons and phylloclade) were fixed in FPA 50 and later transferred into alcohol $70 \%$, following the protocol of Johansen (1940). The material was embedded in historesin (Gerrits, 1991), sectioned (cross- and longitudinal sections) in a rotary microtome, and stained in Toluidine Blue (O'Brien et al., 1965). Seedlings were also analyzed in freehand sections stained in Astra Blue and Safranin (Souza et al., 2005).

The histochemical tests for lipid (Sudan III), starch (iodine-potassium iodide test), lignin (phloroglucin test), and mucilage (methylene blue test) were carried out following the procedures by Costa (1972) and Berlyn and Miksche (1976). Illustrations were prepared using New Optical System stereomicroscope and Olympus BX50 optical microscope with digital camera using the software Zoom Browser EX 4.6. All samples were prepared on the same micrometric scale.

\section{Results}

Seedling morphology. Seeds of the 3 species (Figs. 1A, 2A, $3 \mathrm{~A})$ were operculate and brown dark or black. Germination started with the emergence of the embryo axis (Figs. 1B-E, 3B,C). The embryo and seedling were white initially and assumed the green color gradually in the presence of light (Figs. 1D-G, 2B-D, 3B-D). The primary root grew very slowly (Figs. 1F-J, 2B-G, 3D-G) being characterized as axial and ramified. On the lower end of the hypocotyl (collet) grew out a great number of long slender straight hairs, which attached themselves to the substratum (Figs. $2 \mathrm{~J}, 3 \mathrm{~F})$. Adventitious roots may be formed in the collet region (Figs. 1J-M, 2G-I, 3G,H).

The hypocotyl (Figs. 1H-M, 2C-K, 3D-K) was green, succulent, and differed in size and thickness in the 3 species, being more elongated in $R$. cereuscula (about $5 \mathrm{~mm}$ ) and presenting a larger width in $R$. floccosa and $L$. cruciforme (about $2.5 \mathrm{~mm}$ ).

The cotyledons, normally 2 , were small, green, sessile, succulent, and presented pointed apex (Figs. 1G-M, 2B-L, $3 \mathrm{D}-\mathrm{K})$. There were seedlings with a third cotyledon (Fig. $3 \mathrm{~J})$. With further growth in diameter of the hypocotyls, the cotyledons broadened at the base and gradually became merged into the stem (Figs. 1K-M, 2G-K, 3H-K).

The succulent epicotyl (phylloclade) initially had 
tubercles (Figs. 1J-L, 2F-G, 3F-G), forming a more or less gradual transition to the ribbed-stem, and areoles with long rigid pointed spines and short trichomes (Figs. $1 \mathrm{~L}-\mathrm{M}, 2 \mathrm{H}-\mathrm{K}, 3 \mathrm{H}-\mathrm{K})$. The number of ribs varied among the species, being 4 ribs in $R$. cereuscula, 5 in $R$. floccosa, and 3 in L. cruciforme.

Seedling anatomy. In twenty-day old seedling, the proximal root region (Fig. 4) and the collet had a glabrous uniseriate epidermis with an outer periclinal wall thicker than the internal. The cortex was parenchymatous with an endodermis without Casparian strips. The central cylinder had parenchymatous one layer pericycle, 2 phloem strands, and tracheary elements situated between the 2 phloem groups. The roots were diarch.

The hypocotyl had a relatively uniform structure in almost all its length (Fig. 5). The glabrous cutinized unistratose epidermis (Fig. 5A) presented cuboid or papillate cells, and parallelocytic stomata. In a surface view, the epidermal cells were elongated and narrow, with wavy anticlinal walls, which were more pronounced in R. floccosa (Fig. 5F) and L. cruciforme. The cortex had chlorophyllous parenchyma with thin-walled cells of variable sizes. Rhipsalis species showed abundant starch in the cortical cells, mainly R. floccosa (Fig. 5A, B). Cortex contained mucilage cells and the hypodermis was absent. Idioblasts with calcium oxalate crystals were present in the cortex, being druses in Rhipsalis and either druses or monocrystals in L. cruciforme. The central cylinder close to the root presented a reduced diameter with the tracheary elements between 2 phloem strands (Fig. 5B). Close to cotyledon node, the epidermis and cortex resembled those of the hypocotyl base. Whereas, in the central cylinder, the 2 phloem strands underwent bifurcation and rotation; thus, the cotyledonary and epicotyledonary traces were formed. With the redistribution of the central tracheary elements, a parenchymatous pith was formed (Fig. 5C-E). Therefore, in the cotyledonary node region, the change from the exarch condition to the endarch condition occurred.

Cotyledons (Fig. 6) consisted of glabrous uniseriate epidermis with parallelocytic stomata. The mesophyll was parenchymatous and chlorophyllous with mucilage cells and a small collateral vascular bundle.

The epicotyl (phylloclade) had variable outline in cross-section being circular in $R$. floccosa, trapezoidal in $R$. cereuscula, and triangular in L. cruciforme (Fig. 7). The 3 species had a cutinized glabrous unistratose epidermis (Fig. 7) with parallelocytic stomata exhibiting a random orientation. The epidermal cells were tabular and papillate in cross-section, and in surface view, they had polyhedral shape with wavy anticlinal walls. Spines and trichomes occurred in the areoles (Fig. 7B,C,E). Spines consisted of thick-walled fiber cells. Trichomes were small, pluricellular with rounded apex. The cortex (Fig. 7) was formed by parenchyma cells with thin-walled, chlorophyllous cells, and mucilage cells except for $R$. cereuscula (Fig. 7F) with a slightly thick-walled collenchymatous one layer hypodermis. Rhipsalis species showed cortical idioblasts with druses, while L. cruciforme possessed small amount of druses, and more abundant prismatic, cuboidal, and rhomboidal crystals. The central cylinder (Fig. 7A,B,C,F) consisted of collateral vascular bundles, and a small parenchymatous pith.

\section{Discussion}

Seeds of the 3 species studied had a rigid integument and germinated by a seed lid (operculum). Opercula are widespread among angiosperms and are reported in 25 monocotyledonous and 20 dicotyledonous families (Bregman and Bouman, 1983). These authors revised the seeds of 103 species of Cactaceae belonging to 89 genera, and they registered the presence of operculum in most of cacti seeds, including the tribe Rhipsalideae. As shown by Bregman and Bouman (1983), a tough testa found in Cactaceae seeds prevents early desiccation, mechanical damage, predation, and microbial attack of the embryo.

After germination, long hairs grow out in the collet region of the 3 species studied which can aid the initial fixation of the seedlings to the substratum. Almeida (2009) also registered collet hairs in the Epiphyllum phyllanthus epiphyte suggesting that they chiefly serve as anchorage structures in the seedling establishment in tree trunks.

Fraine (1910) examined seedlings of 47 species of Cactaceae that can be classified into 2 groups so far as their external morphology is concerned. The first of these groups includes those seedlings which bear a more or less close resemblance to those of an ordinary dicotyledon, having a long hypocotyl and distinctly leafy-cotyledons. The 3 species studied in our research may be included in the second group which do not bear a close resemblance to those of an ordinary Eudicot. The members of this second group show considerable reduction of length and an increase in succulence if compared with the seedlings of the first group. In addition, the hypocotyl is always short, ovoid or globular in shape, while the cotyledons are small, pointed structures, often microscopic in size. This description agrees with most cacti seedlings described so far (Ganong, 1898; Hamilton, 1970; Bona et al., 1997; Loza-Cornejo et al., 2003; Almeida et al., 2009).

In the 3 species studied, the root-stem transition region of the seedlings began in the collet and continued along the hypocotyl, reaching completion near its summit, within 
the system connecting the cotyledons with the root. The reorientation of the exarch condition typical of the root to the endarch only occurs in the cotyledonary node; here the traces of the 2 cotyledons and the epicotyledonary are formed. This transition type is relatively simple and found in dicotyledons (Esau, 1965; Souza, 2009) but Fraine (1910) registered only protoxylem cells throughout the whole length of the hypocotyl of Rhipsalis warmingiana K. Schum. and Rhipsalis dissimilis K. Schum.

The cotyledonary vascularization of Rhipsalis and Lepismium shows differences when compared with the Opuntia (Freeman, 1969). In Opuntia, in addition to the central bundle, each cotyledon has 2 lateral traces each formed by the divergence of a single hypocotyl bundle. In contrast, each cotyledon of Rhipsalis and Lepismium was vascularized by a single bundle.

In the subepidermal cells of the hypocotyl and epicotyl calcium oxalate crystals were observed, being druses in the 2 Rhipsalis species and both druses and monocrystals in Lepismium cruciforme. In fact, it should be pointed out that in Cactoideae the occurrence of calcium oxalate druses and prismatic crystals is very common (Terrazas and Arias, 2003). The druses had the same shape in the species studied; however, Hartl et al. (2007) registered druses of calcium oxalate dihydrate for Lepismium, and druse of calcium oxalate monohydrate for Rhipsalis, when their hydration state.

Hypocotyl, cotyledons, and epicotyl are structurally similar in the 3 species studied, presenting basic anatomical features of Cactaceae (Barthlott and Hunt, 1993) and Cactoideae (Terrazas and Arias, 2003), such as uniseriate epidermis, parallelocytic stomata, cortex with water-storage parenchyma, idioblasts with calcium oxalate crystals, and mucilage cells. With reference to the vascular cylinder, R. cereuscula, R. floccosa and L. cruciforme showed a reduced amount of primary phloem and xylem.

Fibers that differentiate adjacent to the phloemconducting cells were registered in Rhipsalideae (Terrazas and Arias, 2003), but they were not observed in seedlings of $R$. cereuscula, R. floccosa and L. cruciforme. Maybe fibers outside phloem of these species differentiate in advanced development stage.

A collenchymatous hypodermis generally occurs under the stem epidermis (Cronquist, 1981; Barthlott and Hunt, 1993; Mauseth, 2006), and usually consists of more than one layer in stems of Cactoideae, although it has been secondarily lost in several taxa (Terrazas and Arias, 2003). Dettke and Milaneze-Gutierre (2008) observed a collenchymatous hypodermis in the mature shoot of Rhipsalis cereuscula and Lepismium cruciforme. Calvente et al. (2008) also observed thick-walled hypodermal cells in $R$. teres (Vell.) Steudel and $R$. pentaptera Pfeiff ex A.
Dietr. However, a weakly developed hypodermal layer was only observed in the epicotyl (phylloclade) of $R$. cereuscula. The cell wall thickness of the hypodermis in $R$. cereuscula may be related to the xeromorphy caused by epiphytic habitat, in agreement with considerations for Rhipsalis species (Calvente et al., 2008).

The vascular bundles were absent from the narrow pith of the hypocotyl and epicotyl of the 3 cacti species. All members of Cactoideae have medullary bundles with following exceptions: Rhipsalideae, Hylocereeae and some species of Cacteae and Notocacteae (Mauseth, 1993). Mauseth suggests that medullary bundles and broad pith seem to be selectively advantageous in withstanding water stress. The narrow and unvascularized pith in members of Rhipsalideae may be due to the epiphytic habit occupying more mesic environments (tropical forests) and non deserts as typical cacti (Calvente et al., 2008).

Stomata frequencies for cacti are low compared with leaves of $\mathrm{C}_{3}$ and $\mathrm{C}_{4}$ species (Terrazas Salgado and Mauseth, 2002), and the orientation of the pore in relation to the long axis of the plant is taxonomically important (Metcalfe and Chalk, 1950). For taxa of the Cactoideae, no general statement on the orientation of stomata can be made. Most groups exhibit a random orientation, but only a few show certain constancy, particularly the epiphytic cacti (Eggli, 1984). Rhipsalis species have stomata pores orientated transversely and longitudinally to the long axis of the shoot (Metcalfe and Chalk, 1950). Dettke and Milaneze-Gutierre (2008) registered that the stomata pores have a transverse orientation in L. cruciforme shoot and a parallel orientation in $R$. cereuscula. With regard to the Lepismium and Rhipsalis seedlings the epicotyl (phylloclade) exhibited a random orientation.

The arrangements of crystalliferous and mucilaginous cells are recorded for stems of certain species of the genera mentioned by Metcalfe and Chalk (1950). In agreement with these authors in Lepismium and Rhipsalis, the mucilaginous and crystalliferous cells occur scattered and together. The epicotyl of the Lepismium and Rhipsalis seedlings shows both cell types of mucilaginous and crystalliferous, but are confined to the outer cortex.

The mostly uniseriate epidermis with thin walled cells covered by a thick hydrophobic cuticle, the collenchymatous hypodermis with many druses, the parenchymatous tissue specialized in photosynthesis and water storage and the presence of cortical bundles are features previously described for Cactaceae (Terrazas Salgado and Mauseth, 2002; Mauseth, 2006), and are observed in the stems of Rhipsalis species (Calvente et al., 2008). On the other hand, both hypocotyl and epicotyl of the Lepismium and Rhipsalis species studied present features which may be relictual in Cactaceae (Mauseth, 1999), 
such as an epidermis predominantly lacking crystals, an absent or weakly developed hypodermis, cortex which is predominantly parenchymatous with druses and mucilage cells, but lacking cortical bundles, and a pith without medullary bundles.

\section{Acknowledgments}

We thank $\mathrm{CNPq}$ ("Conselho Nacional de Desenvolvimento Científico e Tecnológico, Brasil”) for the support granted to the accomplishment of this work (Research grant to L. A. Souza).

\section{Literature cited}

Almeida, O. J. G. 2009. Morfoanatomia dos órgãos reprodutivos e plântula de Epiphylum phyllanthus (L.) Haw. (Cactaceae). Dissertação Mestrado, Universidade Estadual Paulista. Rio Claro, S.P. 100 p.

Almeida, O. J. G.; L. A. Souza and I. S. Moscheta. 2009. Morfo-anatomia da plântula de indivíduos somaclones de Cereus hildmannianus Schumann (Cactaceae). Boletín de la Sociedad Latinoamericana y del Caribe de Cactáceas y otras Suculentas 6:29-35.

Barthlott, W. and D. R. Hunt. 1993. Cactaceae. In II Flowering Plants - dicotyledons (Magnoliid, Hammamelid and Caryophyllid families), K. Kubitzki (ed.). Springer-Verlag, Berlin. p. 161-171.

Berlyn, G. P. and J. P. Miksche. 1976. Botanical Microtechnique and Cytochemistry. The Iowa State University Press, Ames, Iowa. $326 \mathrm{p}$.

Bona, C.; M. Kaehler, N. K. Takemori, A. C. Cervi and Y. Alquini. 1997. Análise morfo-anatômica de Hatiora gaertneri (Regel) Barthlott (Cactaceae). Arquivos de Biologia e Tecnolologia 40:752-759.

Bregman, R. and F. Bouman. 1983. Seed germination in Cactaceae. Botanical Journal of the Linnean Society 86:357374.

Calvente, A.; R. H. P. Andreata and R. C. Vieira. 2008. Stem anatomy of Rhipsalis (Cactaceae) and its relevance for taxonomy. Plant Systematic and Evolution 276:271-277.

Costa, A. F. 1972. Farmacognosia (farmacognosia experimental). Fundação Calouste Gulbenkian, Lisboa. 1033 p.

Cronquist, A. 1981. An Integrated System of Classification of Flowering Plants. Columbia University Press, New York. $1262 \mathrm{p}$.

Daubenmire, R. F. 1974. Plants and Environment (a textbook of plant autecology). John Wiley \& Sons, New York. 422 p.

Dettke, G. A. and M. A. Milaneze-Gutierre. 2008. Anatomia caulinar de espécies epífitas de Cactaceae, subfamília Cactoideae. Hoehnea 35:581-593.

Eggli, U. 1984. Stomatal types of Cactaceae. Plant Systematics and Evolution 146:197-214.

Esau, K. 1965. Vascular Differentiation in Plants. Holt, Rinehart and Winston, New York. 160 p.

Fraine, E. 1910. The seedling structure of certain Cactaceae. Annals of Botany 24: 125-175.

Freeman, T. P. 1969. The developmental anatomy of Opuntia basilaris. I. Embryo, root, and transition zone. American Journal of Botany 56:1067-1074.

Ganong, W. F. 1898. Contributions to a knowledge of the morphology and ecology of the Cactaceae: II. The comparative morphology of the embryos and seedlings. Annals of Botany 12:423-476.

Gerrits, P. O. 1991. The Application of Glycol Methacrylate in Histotechnology: some fundamental principles. University Groningen, Netherlands. $80 \mathrm{p}$.

Hamilton, M. W. 1970. Seedling development of Opuntia brandtiana (Cactaceae). American Journal of Botany 57:599603.

Hartl, W. P., H. Klapper, B. Barbier, H. J. Ensikat, R. Dronskowski, P. Müller, G. Ostendorp, A. Tye, R. Bauer and W. Barthlott. 2007. Diversity of calcium oxalate crystals in Cactaceae. Canadian Journal of Botany 85:501-517.

Johansen, D. A. 1940. Plant Microtechnique. 2. ed. Tata McGrawHill Book Company, Bombay. 523 p.

Judd, W. S., C. S. Campbell, E. A. Kellogg, P. F. Stevens and M. J. Donoghue. 2002. Plant Systematics - a phylogenetic approach. 2. ed. Sinauer Associates, Sunderland. 576 p.

Loza-Cornejo, S., T. Terrazas, L. López-Mata and C. Trejo. 2003. Características morfo-anatómicas y metabolismo fotossintético em plántulas de Stenocereus queretaroensis (Cactaceae): su significado adaptativo. Interciencia 28:1-26.

Mauseth, J. D. 1993. Medullary bundles and the evolution of cacti. American Journal of Botany 80:928-932.

Mauseth, J. D. 1999. Anatomical adaptations to xeric conditions in Maihuenia (Cactaceae), a relictual, leaf-bearing cactus. Journal of Plant Research 112:307-315.

Mauseth, J. D. 2006. Structure-function relationships in highly modified shoots of Cactaceae. Annals of Botany 98:901-926.

Metcalfe, C. R. and L. Chalk. 1950. Anatomy of the Dicotyledons (leaves, stem, and wood in relation to taxonomy with notes on economic uses). Clarendon Press, Oxford. 1500 p.

Millanez, C. R. D., D. M. Oliveira and M. A. Moraes-Dallaqua. 2008. Semi-hypogeal germination in Pachyrhizus ahipa (Wedd.) Parodi (Fabaceae: Phaseoleae): seedling and sapling morphology. Brazilian Archives of Biology and Technology 51:353-359.

O’Brien, T. P., N. Feder and M. E. Mccully. 1965. Polycromatic staining of plant cell walls by toluidine blue O. Protoplasma 59:368-373 
Salles, H. G. 1987. Expressão morfológica de sementes e plântulas. I. - Cephalocereus fluminensis (Miq) Britton e Rose (Cactaceae). Revista Brasileira de Sementes 9:73-81.

Simão, E., F. Socolowski and M. Takaki. 2007. The epiphytic Cactaceae Hylocereus setaceus (Salm-Dick ex DC.) Ralf Bauer seed germination is controlled by light. Brazilian Archives of Biology and Technology 50:655-662.

Souza, L. A. 2003. Morfologia e Anatomia Vegetal (célula, tecidos, órgãos e plântula). Editora Universidade Estadual de Ponta Grossa, Ponta Grossa. 258 p.

Souza, L. A. 2009. Anatomia da plântula e do tirodendro. In Sementes e plântulas - germinação, estrutura e adaptação, L. A. Souza (org.). Todapalavra Editora, Ponta Grossa. p. 193-252.
Souza, L. A., S. M. Rosa, I. S. Moscheta, K. S. M. Mourão, R. A. Rodella, D. C Rocha and M. I. G. A. Lolis. 2005. Morfologia e Anatomia Vegetal (técnicas e práticas). Editora Universidade Estadual de Ponta Grossa, Ponta Grossa. 194 p. Souza, V. C. and H. Lorenzi. 2005. Botânica Sistemática - guia ilustrado para identificação das famílias de angiospermas da flora brasileira, baseado em APG II. Instituto Plantarum de Estudos da Flora, Nova Odessa. 640 p.

Terrazas, T. and S. Arias. 2003. Comparative stem anatomy in the subfamily Cactoideae. The Botanical Review 68:444-473.

Terrazas Salgado, T. and J. D. Mauseth. 2002. Shoot anatomy and morphology. In Cacti: biology and uses, P. S. Nobel (ed.). University of California Press, Ewing. p. 23-39. 


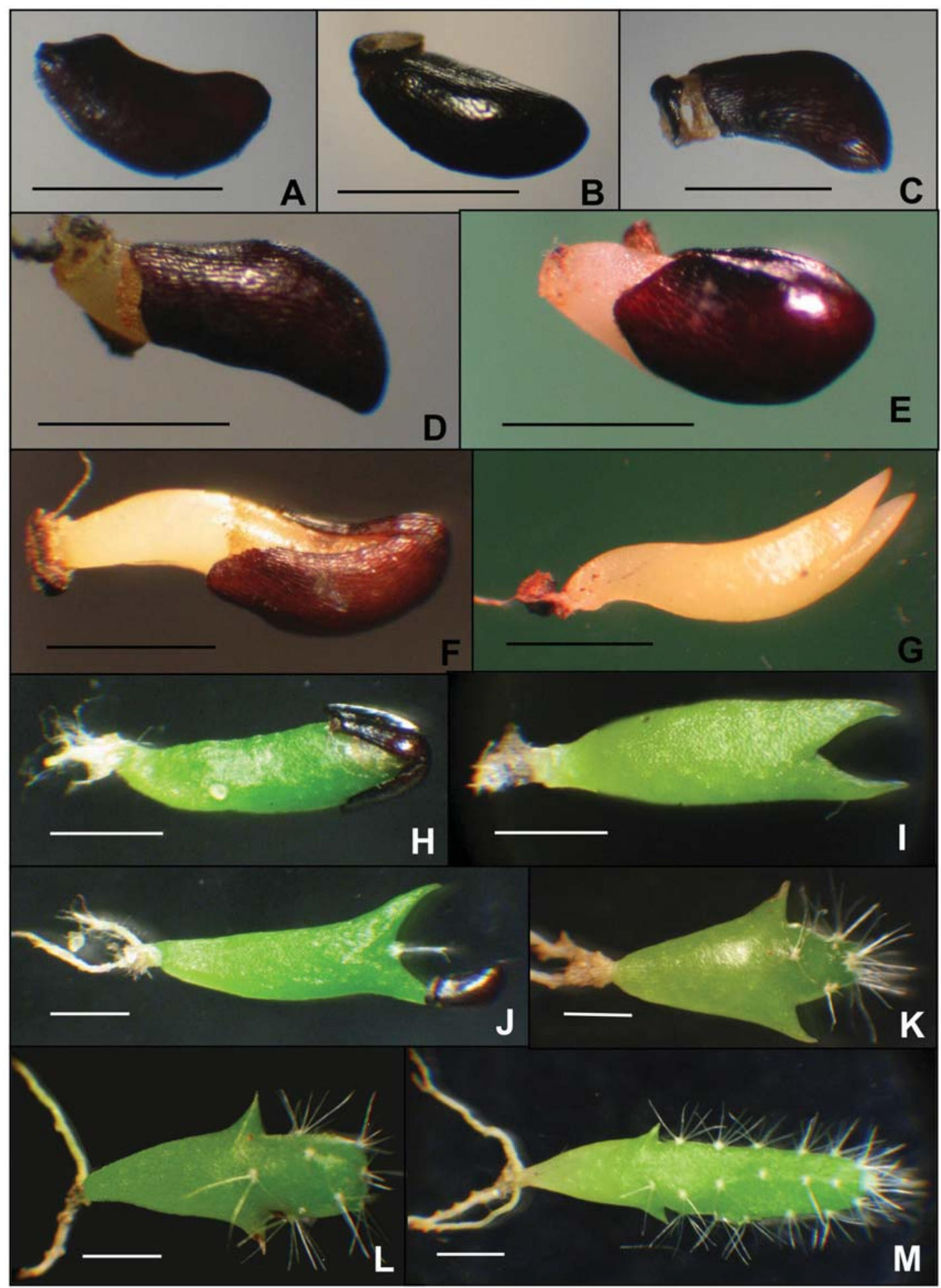

Figure 1. Seed and seedling of Rhipsalis cereuscula. A, seed; B, germination by an operculum; C, D, E, and F, 1-day, 2-, 2-, and 4-days seedlings; G, H, and I, 6-, 8- and 15-days seedlings showing cotyledons, hypocotyl and root development; J, K, L, and M, 30-, 50-, 80-, and 160-days seedlings with epicotyl (phylloclade) in development. Bar = $1 \mathrm{~mm}(\mathrm{~A}-\mathrm{L}), 2 \mathrm{~mm}(\mathrm{M})$. 


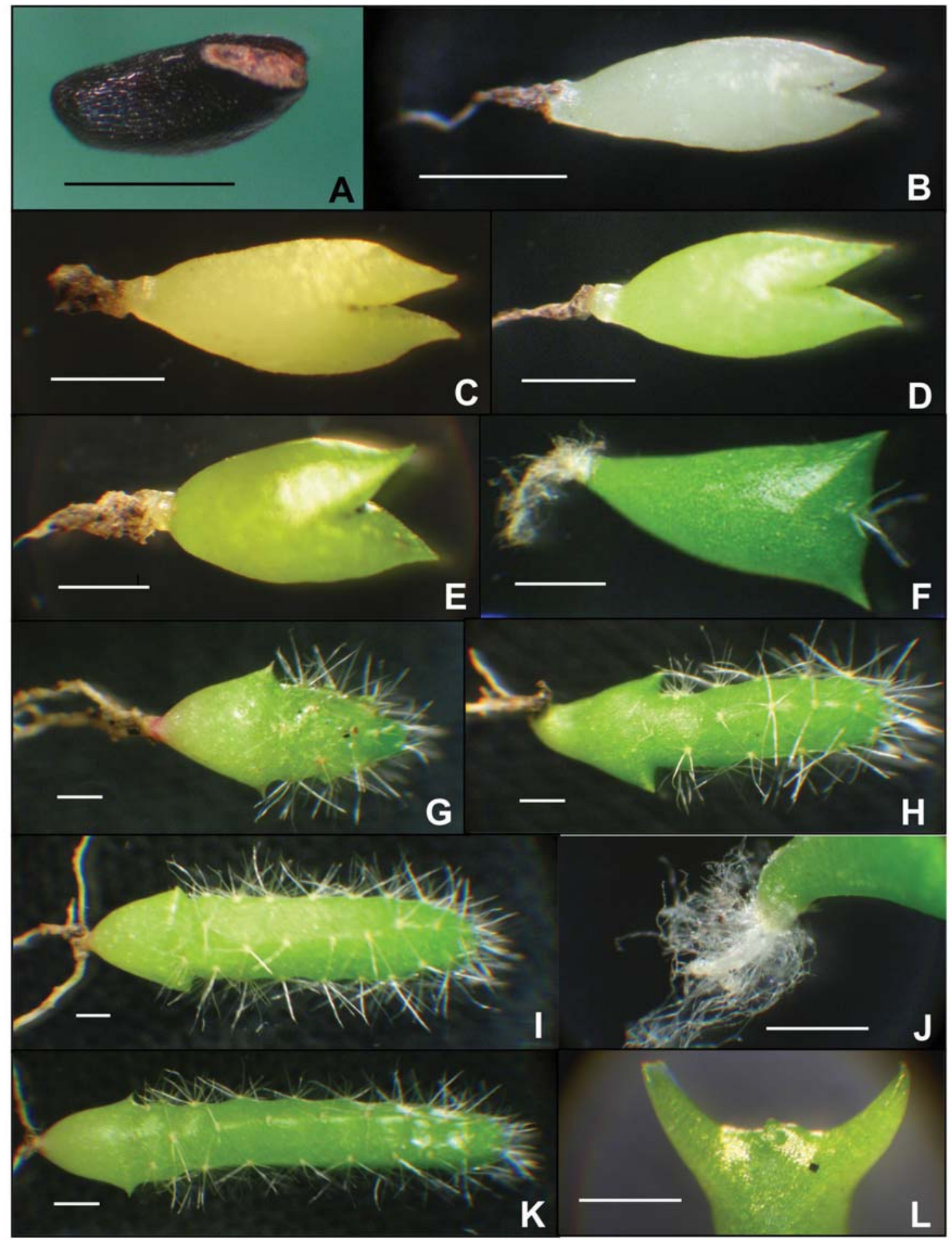

Figure 2. Seed and seedling of Rhipsalis floccosa subsp. hohenauensis. A, seed; B, C, D, and E, 6-, 8-, 10-, and 15-days seedlings showing cotyledons and hypocotyls; F, G, H, I, and K, 20-, 50-, 100-, 130, and 200-days seedlings with epicotyl (phylloclade) in development; J, 15-days seedling showing hypocotyl base and collet with hairs; L, 30-days seedling showing the cotyledonary node region. $\mathrm{Bar}=1 \mathrm{~mm}$. 

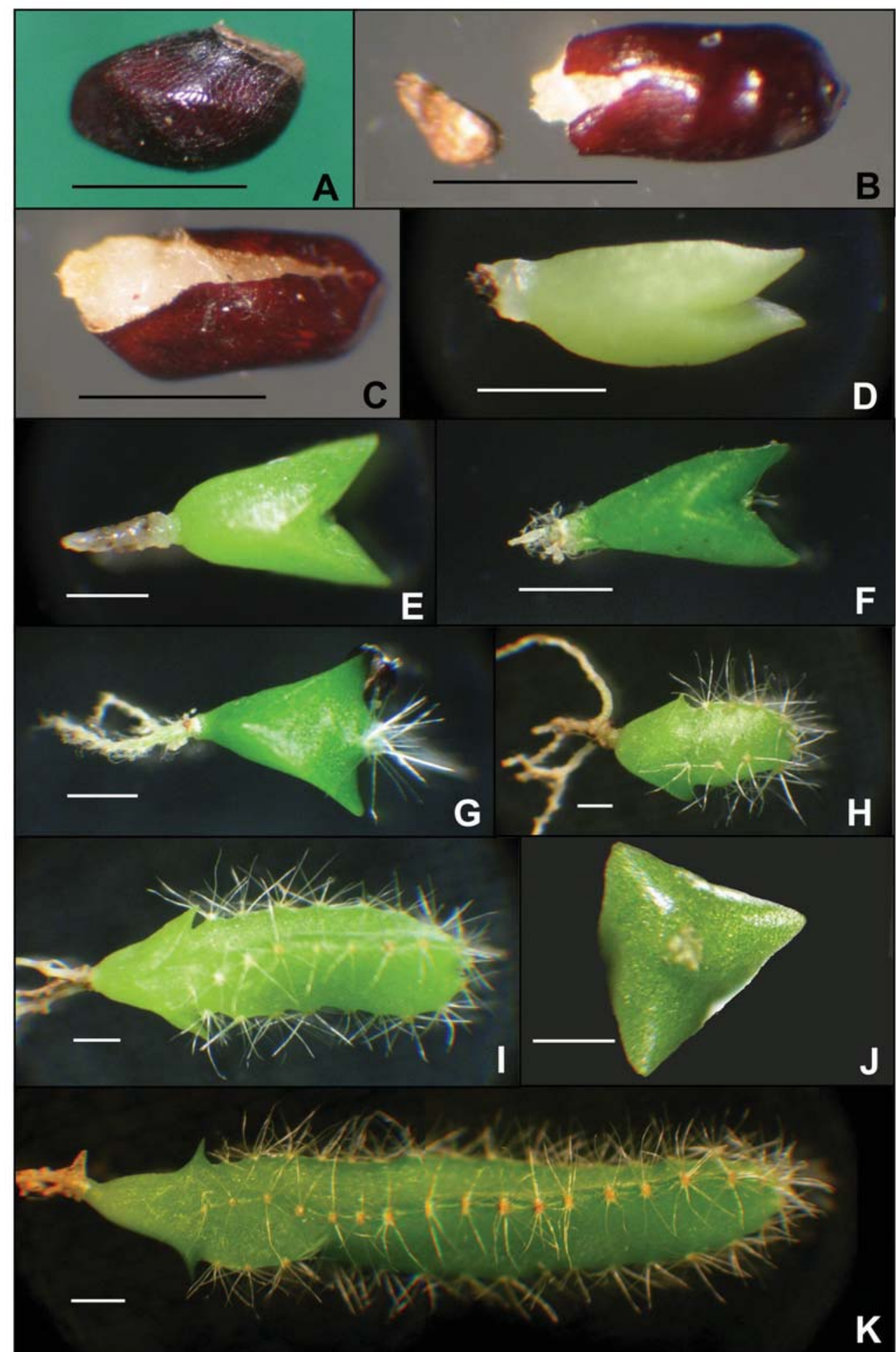

Figure 3. Seed and seedling of Lepismium cruciforme. A, seed; B, seed germination and operculum; C, D, and E, 1-, 12-, and 18-days seedlings; F, G, H, I, and K, 25-, 40-, 60-, 120-, and 200-days seedlings with epicotyl (phylloclade) in development; J, 15-days seedling with 3 cotyledons. $\mathrm{Bar}=1 \mathrm{~mm}$. 

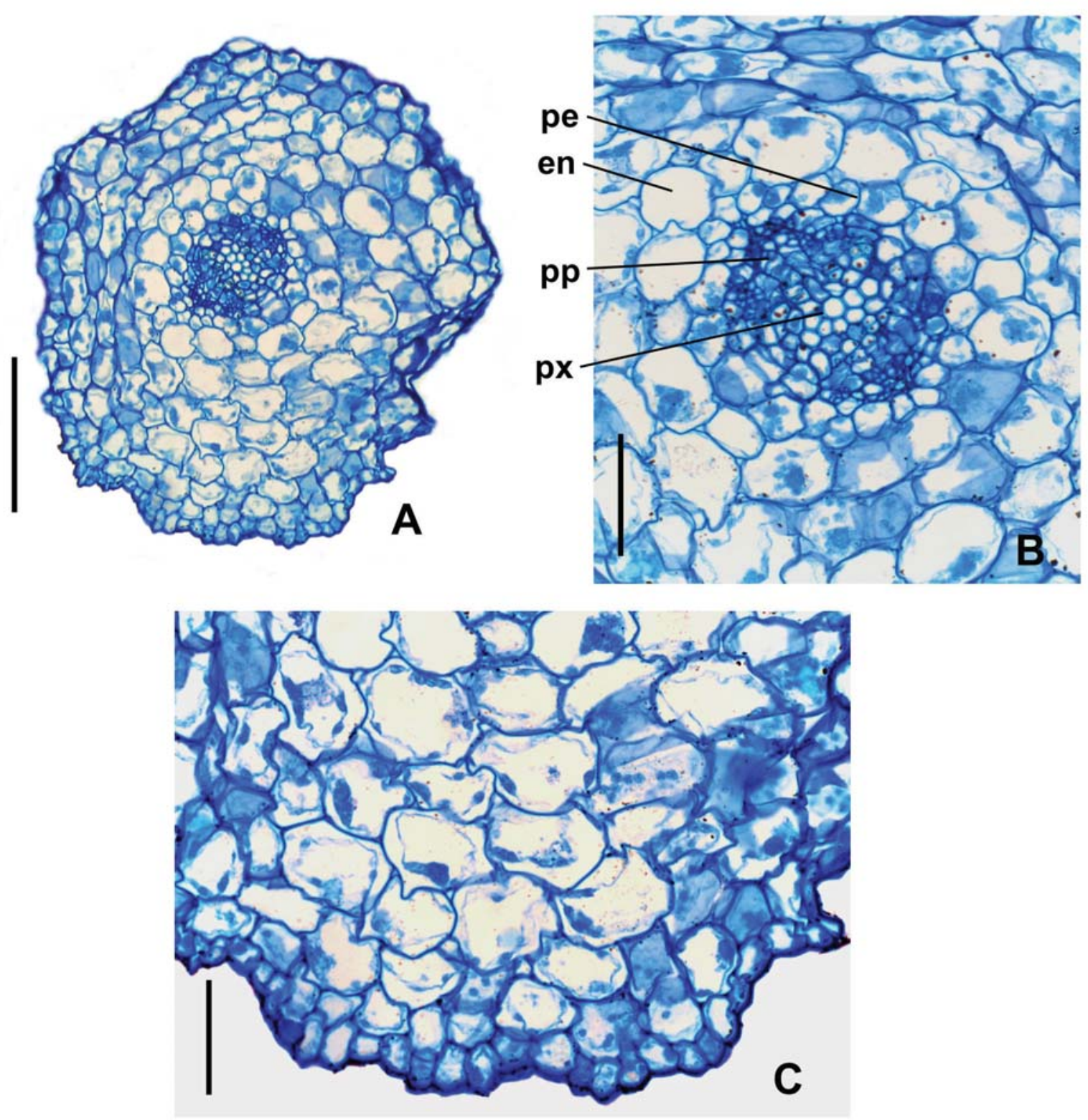

Figure 4. Root cross-sections of the proximal region of Rhipsalis floccosa subsp. hohenauensis, 20-days seedling. A, general view; B, cortex and central cylinder; $\mathrm{C}$, epidermis and cortex. $\mathrm{en}=$ endodermis, $\mathrm{pe}=$ pericycle, $\mathrm{pp}=$ primary phloem, $\mathrm{px}=$ primary $\mathrm{xylem}$. Bar $=150 \mu \mathrm{m}(\mathrm{A})$ and $50 \mu \mathrm{m}(\mathrm{B}, \mathrm{C})$. 

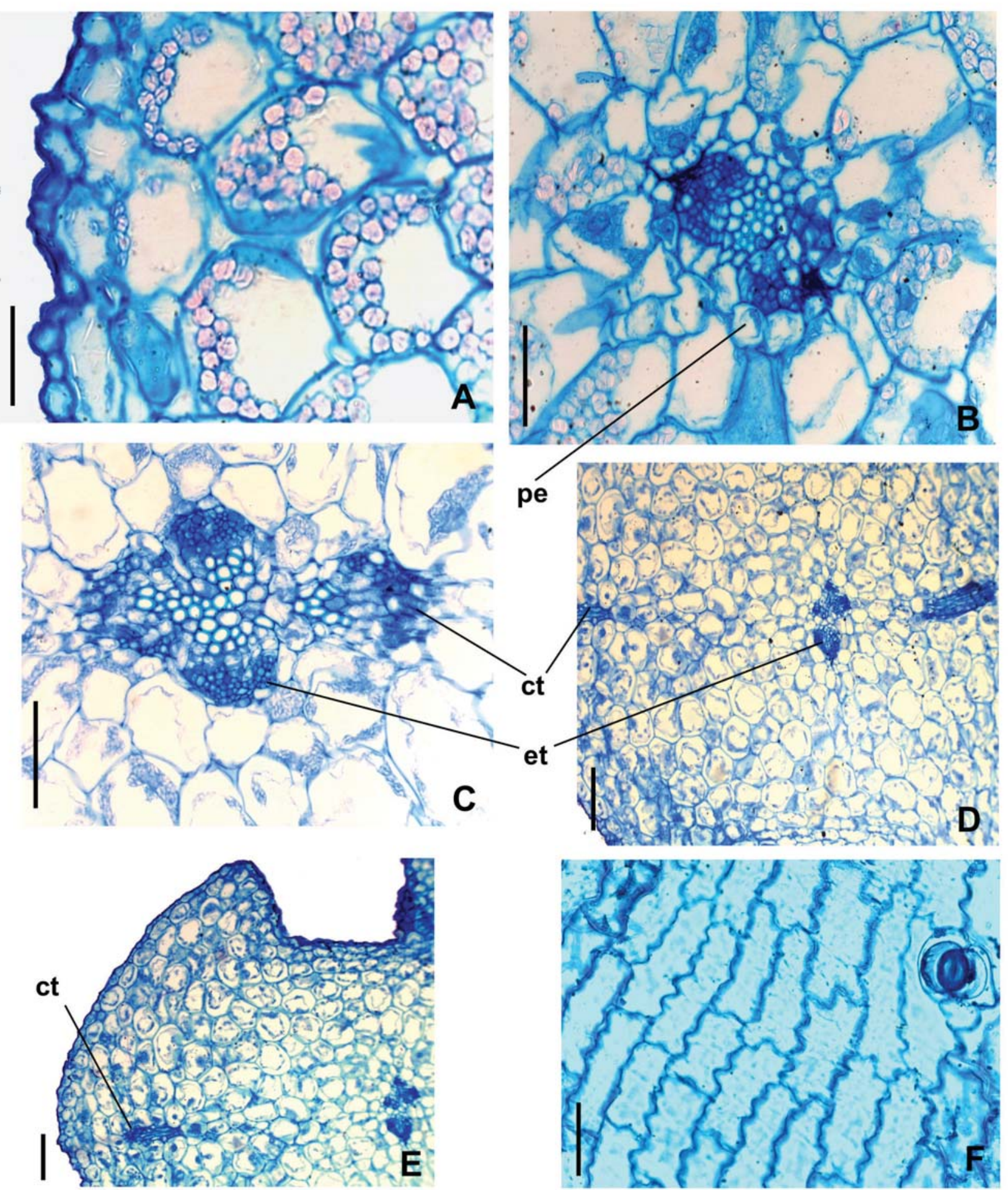

Figure 5. Hypocotyl structure of Rhipsalis floccosa subsp. hohenauensis, 50-days seedling in paradermal and cross-sections. A, epidermis and cortical cells with starch; B, cortex and central cylinder; C, section close to cotyledonary node; D and E, cotyledonary node; F, epidermis in surface view. $\mathrm{ct}=$ cotyledonary trace, et $=$ epicotyledonary trace, $\mathrm{pe}=$ pericycle. $\mathrm{Bar}=150 \mu \mathrm{m}(\mathrm{A}, \mathrm{B}, \mathrm{C}, \mathrm{F}), 50 \mu \mathrm{m}(\mathrm{D}, \mathrm{E})$. 

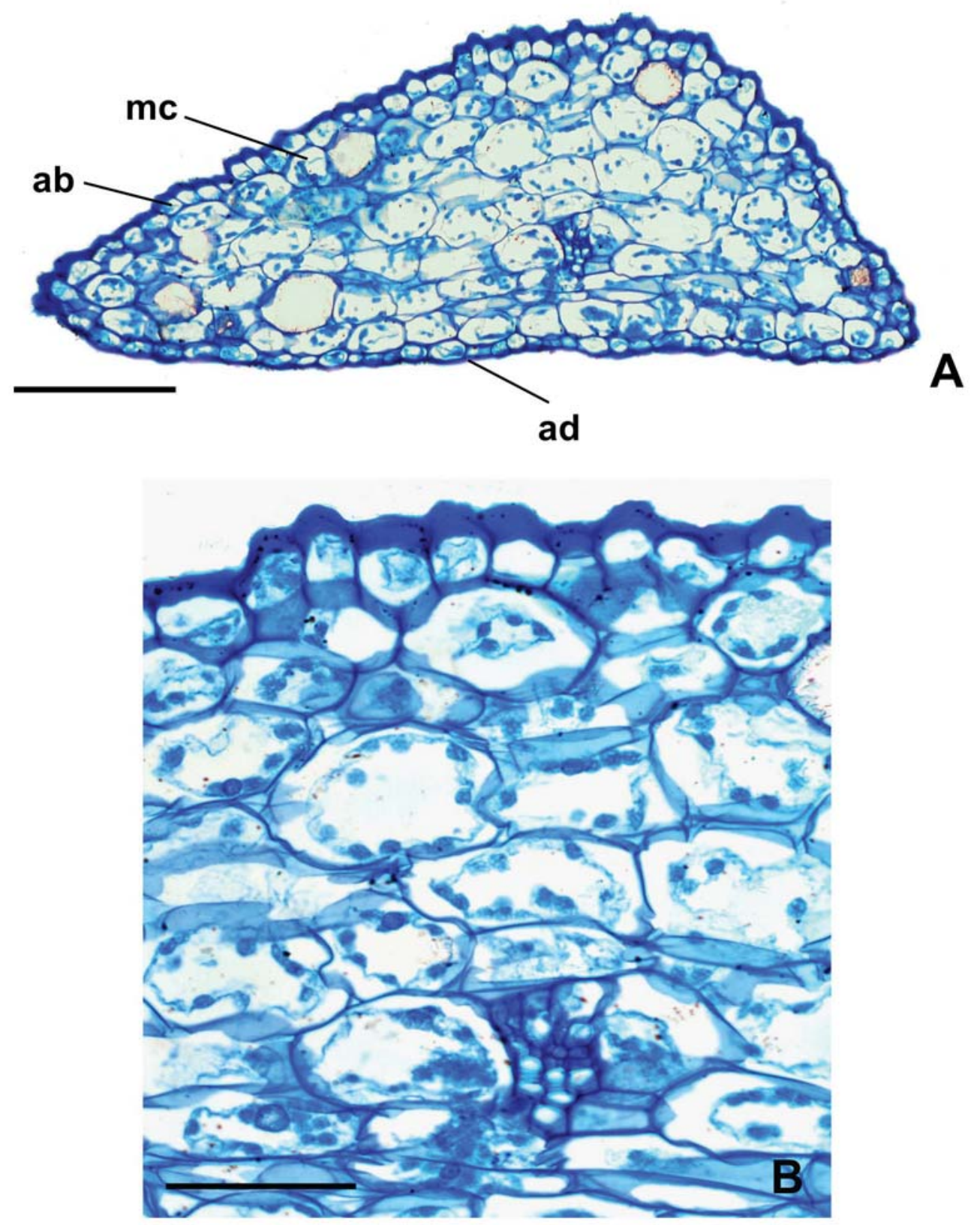

Figure 6. Cotyledon structure of Rhipsalis floccosa subsp. hohenauensis, 30-days seedling in cross-section. A, general view; B, epidermis, mesophyll and vascular bundle of the abaxial region. $\mathrm{ab}=$ abaxial epidermis, $\mathrm{ad}=$ adaxial epidermis, $\mathrm{mc}=$ mucilage cell. $\mathrm{Bar}$ $=100 \mu \mathrm{m}(\mathrm{A}), 50 \mu \mathrm{m}(\mathrm{B})$. 

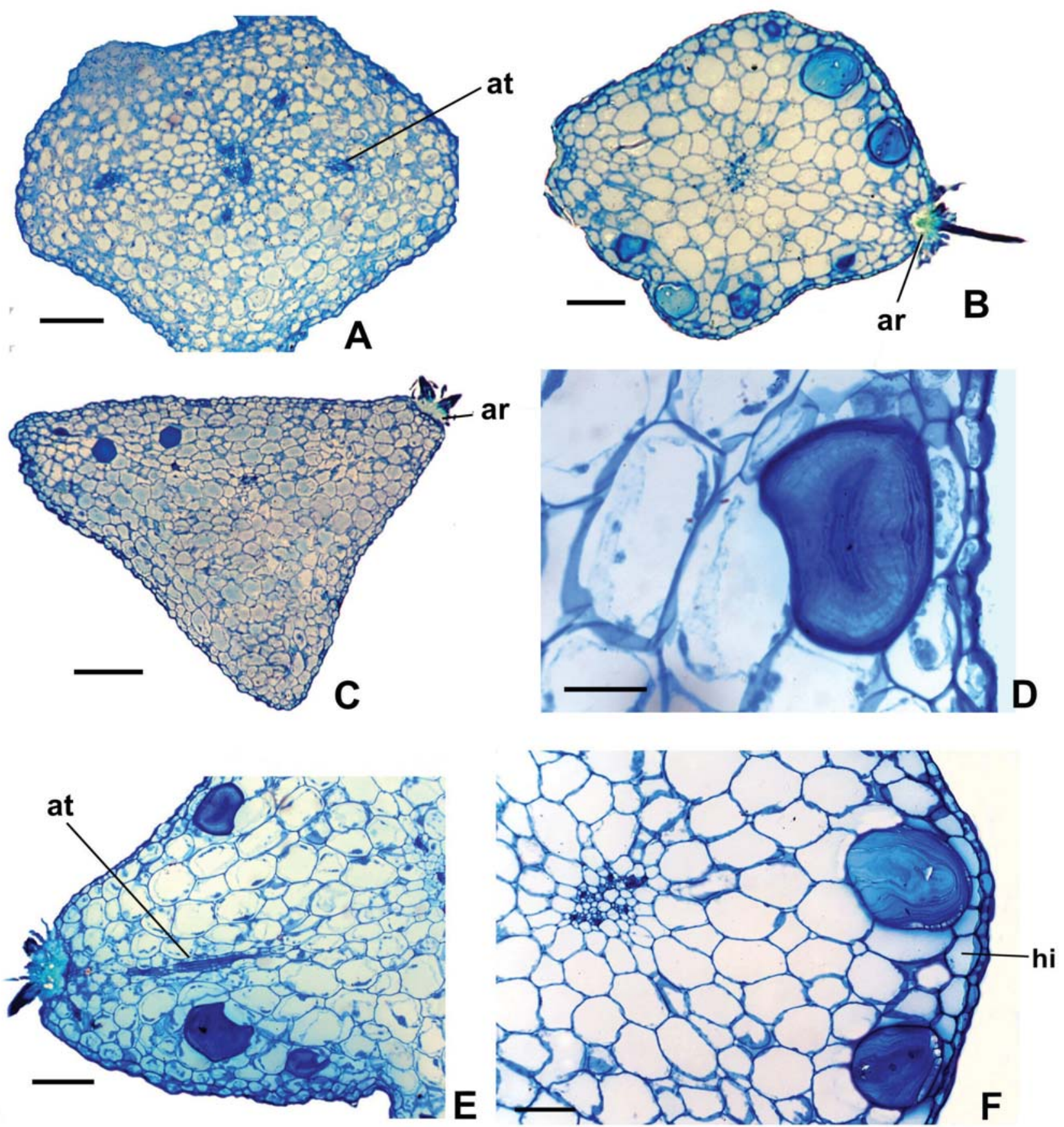

Figure 7. Epicotyl (phylloclade) of Rhipsalis and Lepismium in cross-sections. A, D, and E, R. floccosa subsp. hohenauensis, 130-day seedling; B and F, R. cereuscula, 120-days seedling; C, L. cruciforme, 120-days seedling. A, B, and C, epicotyl outline; D, epidermis and cortex with mucilage cell; $\mathrm{E}$, detail of the rib; F, epidermis, cortex and central cylinder. ar $=$ areole, at $=$ areole trace, $h i=$ hypodermis. Bar $=150 \mu \mathrm{m}(\mathrm{A}), 200 \mu \mathrm{m}(\mathrm{B}, \mathrm{C}), 50 \mu \mathrm{m}(\mathrm{D}), 150 \mu \mathrm{m}(\mathrm{E}, \mathrm{F})$ 
